\title{
Risk factors for mortality of patients undergoing coronary artery bypass graft surgery
}

\author{
Fatores de risco para mortalidade de pacientes submetidos à revascularização miocárdica
}

\author{
Carlos Alberto dos Santos ${ }^{1}$, MD, PhD; Marcos Aurélio Barboza de Oliveira ${ }^{1}, \mathrm{MD}, \mathrm{MsC}$; Antônio \\ Carlos Brandi ${ }^{1}$, MD; Paulo Henrique Husseini Botelho ${ }^{1}$, MD; Josélia de Cássia Menin Brandi ${ }^{1}$, MD; \\ Marcio Antônio dos Santos ${ }^{1}$, MD; Moacir Fernandes de Godoy ${ }^{1}$, MD, PhD; Domingo Marcolino \\ Braile $^{1}, \mathrm{MD}, \mathrm{PhD}$
}

\section{Abstract}

Introduction: Coronary artery bypass grafting is a safe procedure performed worldwide with low rates of mortality and morbidity in general population.

Objective: To investigate risk factors for mortality of patients undergoing coronary artery bypass grafting coronary artery bypass grafting surgery.

Methods: A total of 1,628 consecutive patients undergoing on-pump coronary artery bypass grafting were retrospectively studied from December 1999 to February 2012. Data analysis involved paired Student $t$ test, Mann-Whitney test and Fisher's exact test for the categorical data. Logistic regression, Odds Ratio and $95 \%$ CI were used for definition of risk factors for mortality.

Results: Of a total of 1,628 patients undergoing on-pump coronary artery bypass grafting, $141(8.7 \%)$ died. The following risk factors for mortality were identified after logistic regression: dialysis $(\mathrm{OR}=7.61 ; 95 \% \mathrm{CI} 3.58-16.20)$, neurologic dysfunction type I $(\mathrm{OR}=4.42 ; 95 \%$ CI 2.48-7.81), use of IABP $(\mathrm{OR}=3.38 ; 95 \% \mathrm{CI}$ 1.98-5.79), cardiopulmonary bypass time $(\mathrm{OR}=3.09$; 95\%CI 2.04-4.68), serum creatinine on admission and peak values $>0.4 \mathrm{mg} / \mathrm{dL}(\mathrm{OR}=2.67 ; 95 \% \mathrm{CI} 1.79-4.00)$, age $>65$ years $(\mathrm{OR}=2.31 ; 95 \% \mathrm{CI}$ 1.55-3.44), and time between hospital admission and and surgical procedure $(\mathrm{OR}=1.53$; 95\%CI 1.03-2.27).

Conclusion: Dialysis, type I neurologic dysfunction, use of IABP, cardiopulmonary bypass time ( $>115$ minutes), serum creatinine on admission and peak values $>0.4 \mathrm{mg} / \mathrm{dL}$, age $>65$ years and time between hospital admission and surgical procedure were considered as risk factors for mortality in patients undergoing on-pump coronary artery bypass grafting surgery.

Descriptors: Risk Factors. Myocardial Revascularization. Mortality.

\section{Resumo}

Introdução: Cirurgia de revascularização do miocárdio é um procedimento seguro realizado em todo o mundo com taxas baixas de mortalidade e morbidade na população geral.

Objetivo: Estudar fatores de risco para mortalidade de pacientes submetidos à revascularização miocárdica com circulação extracorpórea.

Métodos: Foram estudados retrospectivamente e de forma consecutiva 1.628 pacientes submetidos à revascularização com circulação extracorpórea no período de dezembro de 1999 a fevereiro
${ }^{1}$ Faculdade de Medicina de São José do Rio Preto (FAMERP), São José do Rio Preto, SP, Brazil.

This study was carried out at Hospital de Base of the Faculdade de Medicina de São José do Rio Preto (FAMERP), São José do Rio Preto, SP, Brazil.

\author{
Correspondence address: \\ Carlos Alberto dos Santos \\ Faculdade de Medicina de São José do Rio Preto \\ Av. Brigadeiro Faria Lima, 5416 - Vila São Pedro - São José do Rio Preto, \\ SP, Brasil - Zip Code: 15090-000 \\ E-mail: carlosburi@terra.com.br
}




\begin{tabular}{|ll|}
\hline Abbreviations, acronyms and symbols \\
\hline AF & Atrial fibrillation \\
AKIN & Acute Kidney Injury Network \\
BMI & Body mass index \\
CABG & Coronary Artery Bypass Grafting \\
CAD & Coronary artery disease \\
CI & Confidence interval \\
CPB & Cardiopulmonary bypass \\
FAMERP & Faculdade de Medicina de São José do Rio Preto \\
HB & Hospital de Base \\
IAB & Intra-aortic balloon \\
ICU & Intensive Care Unit \\
OR & Odds Ratio \\
P & significance level \\
ROC & Receiver Operating Characteristics \\
SIRS & Systemic inflammatory response syndrome \\
STS & Society of Thoracic Surgeons \\
SUS & Unified Health System \\
\hline
\end{tabular}

de 2012. A análise de dados foi efetuada por meio dos testes $t$ de Student não pareado, Mann-Whitney e exato de Fisher para dados categóricos. Regressão logística, Odds Ratio e IC95\% foram utilizados para definição de fatores de risco para mortalidade.

\section{INTRODUCTION}

Cardiovascular diseases are the leading causes of death in the population, including cerebrovascular, cardiac ischemic, hypertensive diseases, atherosclerosis, rheumatic fever and other heart diseases. According to the World Health Organization data in 2008 there were 17.3 million deaths worldwide $^{[1]}$, and 7.3 million were due to coronary artery disease $(\mathrm{CAD})^{[2]}$. In Brazil, in 2009 totaled 209,029 admissions for CHD patients, occurring 12,619 deaths with a mortality rate of $6.04 \%{ }^{[3]}$.

The treatment of CAD may be clinical/medical or surgical. Despite advances in medical therapy and PCI, coronary artery bypass grafting $(\mathrm{CABG})$ is a safe procedure performed worldwide with low rates of mortality and morbidity in the general population ${ }^{[4]}$ and it is still excellent option for treatment of obstructive $\mathrm{CAD}^{[5]}$, even in diabetic patients ${ }^{[6]}$, the elderly ${ }^{[7]}$ and in patients with low left ventricular ejection fraction $^{[8]}$. In addition, the CABG can control the persistent ischemia and progression to acute myocardial infarction, in addition to provide symptomatic relief and prevent ischemic complications ${ }^{[9]}$.
Resultados: Do total de 1.628 pacientes submetidos à cirurgia de revascularização do miocárdio com circulação extracorpórea, $141(8,7 \%)$ foram a óbito. Após regressão logística, foram identificados como fatores de risco para mortalidade as variáveis diálise $(\mathrm{OR}=7,61$; IC 95\% 3,58-16,20), lesão neurológica tipo I $(\mathrm{OR}=4,42$; IC 95\% 2,48-7,81), uso de BIA (OR=3,38; IC 95\% 1,98-5,79), tempo de CEC (OR = 3,09; IC 95\% 2,04-4,68), creatinina pico - admissão $>0,4 \mathrm{mg} / \mathrm{dL}(\mathrm{OR}=2,67$; IC 95\% 1,79 $4,00)$, idade $>65$ anos $(\mathrm{OR}=2,31$; IC 95\% 1,55-3,44) e tempo entre admissão hospitalar e procedimento cirúrgico $(O R=1,53$; IC $95 \%$ 1,03-2,27).

Conclusão: Diálise, lesão neurológica tipo I, uso de balão intra-aórtico, tempo de circulação extracorpórea (> 115 minutos), creatinina pico-admissão $>0,4 \mathrm{mg} / \mathrm{dL}$, idade $>65$ anos e tempo entre admissão hospitalar e procedimento cirúrgico foram considerados como fatores de risco para mortalidade em pacientes submetidos à cirurgia de revascularização do miocárdio com circulação extracorpórea.

Descritores: Fatores de Risco. Revascularização Miocárdica. Mortalidade.

The CABG is the most practiced cardiac surgery in our country, most of which performed by Unified Health System (SUS) both in public hospitals as in philanthropic or private [10]. In the period 2005 to 2007 63,272 CABG were performed in Brazil, with a mortality rate of $6.2 \%{ }^{[10]}$ higher than in countries like the United States $(2.9 \%)^{[11]}$ and Canada $(1.7 \%)^{[12]}$, probably due to the high prevalence of cardiovascular risk factors among Brazilian who underwent $\mathrm{CABG}^{[13]}$. Currently, there is a higher prevalence of poor cardiac conditions and associated comorbidities ${ }^{[14]}$.

The CABG mortality rate may have variation depending on several factors related to pre-, peri- and postoperative. Postoperative variables as length of stay in intensive care unit, atrial fibrillation, acute kidney injury, neurological damage type I and dialysis are related to increased postoperative mortality ${ }^{[14-17]}$.

Considering the importance of $\mathrm{CABG}$ in the correction of myocardial ischemia consequent to the obstruction of the coronary arteries, seeking for the relief of symptoms, improved quality of life, patient return to work, as well as increased life expectancy, we can justify this research, because long-term studies on preoperative, intraoperative and postoperative that 
can influence the mortality of patients undergoing $\mathrm{CABG}$ with $\mathrm{CPB}$ are scarce. Furthermore, it is important to note that all cardiac surgeries were performed by the same team and in a university hospital, with medical residency program in cardiovascular surgery.

The aim of this research was to study risk factors for mortality in the postoperative period in patients undergoing coronary artery bypass grafting with cardiopulmonary bypass (CPB), considering preoperative, intraoperative and postoperative variables and its influence on mortality.

\section{METHODS}

1,674 patients undergoing cardiac surgery for coronary artery bypass grafting with cardiopulmonary bypass (CPB) were retrospectively and consecutively studied, regardless of gender and race at Hospital de Base (HB), São José do Rio Preto, from December/1999 to February/2012. This study was approved by the Research Ethics Committee under opinion 454,518 of $11 / 12 / 2013$.

Of these, $46(2.7 \%)$ were excluded because of failure in the information record in their forms. Patient data were reviewed prospectively by collecting in computerized system.

Were considered as exclusion criteria patients undergoing OPCAB or associated with other cardiac surgery (valvular, ventricular aneurysms, acquired ventricular septal defects, congenital heart diseases) or vascular, in addition to CABG and who died during the intraoperative period.

Data from each patient were obtained in perfusion records of Cardiac Surgery Service of Hospital de Base, including demographic or non-cardiac variables such as gender, age and body mass index (BMI), whereas cardiac variables included time between hospital admission and surgery, use of intraaortic balloon (IAB), cardiopulmonary bypass (CPB) time, total number of grafts, acute atrial fibrillation, respiratory infections, creatinine peak-admission $(\mathrm{mg} / \mathrm{dL})$, dialysis, deep surgical site infection (mediastinitis), neurological damage type I, length of stay in the coronary unit up to 30 days and 30-day mortality.

Were defined as postoperative variables:

Creatinine peak-admission $(\mathrm{mg} / \mathrm{dL})$ : change in serum creatinine defined as the difference between admission creatinine in the Intensive Care Unit (ICU) and the highest value obtained during the stay on this unit.

Cardiac arrhythmias: acute atrial fibrillation lasting longer than 1 hour.

Pulmonary complications: tracheal reintubation due to respiratory failure due to mechanical changes of the ventilation or respiratory infection.

Mediastinitis: mediastinal secretion associated with clinical signs (fever, chest pain) and laboratory (leukocytosis) of infection with or without sternal instability and with secretions culture and positive blood culture. Type I neurological
Table 1. Descriptive statistics for pre-, intra- and postoperative variables in patients undergoing CABG from December/1999 to February/2012 ( $\mathrm{n}=1.628)$.

\begin{tabular}{lccccc}
\hline Variable & mean & sd & median & min & max \\
\hline age $($ years $)$ & 60.7 & 9.4 & 61 & 25 & 91 \\
BMI $\left(\mathrm{Kg} / \mathrm{m}^{2}\right)$ & 27 & 4.2 & 26.6 & 15.3 & 49.3 \\
time of surgery-admission & 6.2 & 5.8 & 4 & 0 & 38 \\
$\begin{array}{l}\text { (d) } \\
\text { Ucor stay up to 30 days (d) }\end{array}$ & 4.1 & 5.2 & 2 & 0 & 30 \\
$\begin{array}{l}\text { Creatinine peak - Intake } \\
\text { (mg/dL) }\end{array}$ & 0.4 & 0.7 & 0.1 & -0.2 & 7.5 \\
Total of grafts & & & & & \\
CPB time (min) & 2.7 & 0.7 & 3 & 1 & 5 \\
& 94.4 & 25.5 & 92 & 24 & 218 \\
\hline
\end{tabular}

Table 2. Percentage distribution of pre- and postoperative variables in patients undergoing CABG from December/1999 to February/2012 $(\mathrm{n}=1.628)$.

\begin{tabular}{lcc}
\hline Variables & $\mathrm{N}(\%)$ & $\mathrm{N}(\%)$ \\
\hline & $\mathrm{M}$ & $\mathrm{F}$ \\
Gender & $1125(69.1)$ & $503(30.9)$ \\
& Presence & Absence \\
IAB & $114(7)$ & $1514(93)$ \\
Acute FA & $141(8.7)$ & $1487(91.3)$ \\
PC & $227(14.4)$ & $1351(85.6)$ \\
Dialysis & $40(2.5)$ & $1588(97.5)$ \\
mediastinitis & $25(1.5)$ & $1603(98.5)$ \\
neurological lesions I & $71(4.4)$ & $1557(95.6)$ \\
\hline
\end{tabular}

$N=$ number of subjects; $M=$ male $; F=$ female; $P C=$ pulmonary complications; $I A B=$ intra-aortic balloon; $A F=$ atrial fibrillation

lesion: new and persistent deficit focal motor, coma, seizures or brain damage.

Deaths: mortality from all causes within 30 days.

\section{Statistical Analysis}

The data were submitted to normality KolmogorovSmirnov test and, subsequently, the parametric analysis by the Student $t$ test or unpaired nonparametric Mann-Whitney test and Fisher's exact test for categorical data. Numerical variables were submitted to the ROC curve for definition of the cutoff point of each in relation to death in the postoperative period. Logistic regression, odds ratio (OR) and $95 \%$ CI were used to define risk factors for mortality in the postoperative period. For other tests, $P<0.05$ was considered significant. We used the program of statistical calculations GraphPad InStat version 3.00 (GraphPad Software, San Diego, California, United States). 


\section{RESULTS}

The results for the preoperative, intraoperative and postoperative variables found in patients undergoing onpump CABG $(n=1,628)$ are in Tables 1 and 2 . The most common included males $(69.1 \%)$, pulmonary complications $(14.4 \%)$, acute atrial fibrillation $(8.7 \%)$ and use of intra-aortic balloon (7\%).

\section{Analytical Variables in Patients who died}

Of the 1,628 patients undergoing CABG with CPB, 141 $(8.7 \%)$ died. The results for the preoperative, intraoperative and postoperative found in these patients are shown in Tables 3 and 4 . The main were male (67\%), pulmonary complications $(40 \%)$, use of intra-aortic balloon (21\%) and neurological damage type I (19\%).

\section{Variables influencing the mortality}

The results of the ROC curve for age, time between hospital admission and surgery, creatinine peak-admission and CPB time are shown in Figure 1.

Age (years) showed cutoff value of 65.128 , sensitivity $54 \%$, specificity $69 \%$, and area under the curve of 0.670 (95\% CI 0.620 to 0.721 ).

With respect to the time between hospital admission and surgery (days) the cutoff value was 5.016, sensitivity 54\%, specificity of $59 \%$ and area under the curve of $0.558(95 \%$ CI 0.506 to 0.609 ).

The change in creatinine peak-admission $(\mathrm{mg} / \mathrm{dL})$ showed cutoff of 0.400 , sensitivity $57 \%$, specificity $82 \%$, and area under the curve of 0.682 ( $95 \%$ CI 0.631 to 0.732 ).

The CPB time (min) showed cutoff value of 115.18 , sensitivity $38 \%$, specificity of $84 \%$ and area under the curve of 0.640 (95\% CI 0.589 to 0.691$)$.

Analyzing risk factors for mortality in patients undergoing CABG with CPB (Table 5), it was observed that the relative risk of patients who used BIA go to death is $238 \%$ higher than those who did not need that type of device for ventricular assistance (OR=3.38, 95\% CI 1.98 to $5.79 ; P<0.0001)$.

Regarding the need for dialysis, the relative risk of death in patients in need of such treatment in the postoperative period is $661 \%$ higher than those not undergoing dialysis $(\mathrm{OR}=7.61,95 \%$ CI 3.58 to $16.20 ; P<0.0001)$.

In patients with neurological injury type $\mathrm{I}$, the relative possibility of death is $342 \%$ higher than those without such lesions $(\mathrm{OR}=4.42,95 \%$ CI 2.48 to $7.81 ; P<0.0001)$.

Considering the age of the patients, the relative chance of subjects $>65$ years to die is $131 \%$ higher than those $<65$ years $(\mathrm{OR}=2.31,95 \% \mathrm{CI} 1.55$ to $3.44 ; P<0.0001)$.

The analysis of time between hospital admission and surgery showed that the relative risk of death is $53 \%$ higher than when this time was $>5$ days $(\mathrm{OR}=1.53,95 \%$ CI 1.03 to 2.27 ; $P=0.0352$ ).
Table 3. Descriptive statistics for pre-, intra- and postoperative variables in patients undergoing CABG who died from December/1999 to February/2012 ( $\mathrm{n}=141)$.

\begin{tabular}{lccccc}
\hline Variables & Mean & sd & Median & Min & Max \\
\hline age (years) & 65.89 & 8.96 & 66 & 35 & 91 \\
BMI $\left(\mathrm{Kg} / \mathrm{m}^{2}\right)$ & 26.46 & 4.89 & 26.22 & 15.27 & 40.35 \\
time of surgery-admission (d) & 7.28 & 6.59 & 6 & 0 & 38 \\
Ucor stay up to 30 days (d) & 6.09 & 7.15 & 2 & 0 & 29 \\
Creatinine peak -Intake & & & & & \\
$(\mathrm{mg} / \mathrm{dL})$ & 1.07 & 1.28 & 0.6 & 0 & 6.3 \\
Total of grafts & 2.80 & 0.74 & 3 & 1 & 4 \\
CPB time (min) & 108.58 & 33.01 & 101 & 24 & 191 \\
\hline
\end{tabular}

$\overline{s d=\text { standard deviation; } \text { min =minimum value; } \max =\text { maximum }}$ value; $B M I=b o d y$ mass index; $d=d a y ;$ Ucor=coronary unit; $C P B=$ cardiopulmonary bypass

Table 4. Percentage distribution of pre- and postoperative variables in patients undergoing CABG who died from December/1999 to February/2012 (n=141).

\begin{tabular}{lcc}
\hline Variables & $\mathrm{N}(\%)$ & $\mathrm{N}(\%)$ \\
\hline \multirow{3}{*}{ Gender } & $\mathrm{M}$ & $\mathrm{F}$ \\
& $95(67)$ & $46(33)$ \\
$\mathrm{IAB}$ & Presense & Absence \\
Acute AF & $30(21)$ & $111(79)$ \\
PC & $23(16)$ & $118(84)$ \\
Dialysis & $56(40)$ & $85(60)$ \\
mediastinitis & $23(16)$ & $118(84)$ \\
Neurological lesions I & $6(4)$ & $135(96)$ \\
\hline
\end{tabular}

$N=$ number of individuals; $M=$ male; $F=$ female; $I A B=$ intra-aortic balloon; $A F=$ atrial fibrillation; $C P=$ pulmonary complications

Table 5. Results of the logistic regression risk factors for mortality in patients undergoing CABG from December/1999 to February/2012 $(\mathrm{n}=1.628)$.

\begin{tabular}{lccc}
\hline Risk factors & OR & CI 95\% & $P$ \\
\hline IAB & 3.38 & $1.98-5.79$ & $<0.0001^{*}$ \\
Dialysis & 7.61 & $3.58-16.20$ & $<0.0001^{*}$ \\
Neurological lesions I & 4.42 & $2.48-7.81$ & $<0.0001^{*}$ \\
Diabetes & 1.38 & $0.92-2.08$ & 0.1168 \\
age $>65$ years & 2.31 & $1.55-3.44$ & $<0.0001^{*}$ \\
BMI $>23,4 \mathrm{Kg} / \mathrm{m}^{2}$ & 0.67 & $0.43-1.05$ & 0.0807 \\
time of surgery-admission & 1.53 & $1.03-2.27$ & $0.0352^{*}$ \\
$>5$ days & & & \\
Creatinine peak - Intake $>$ & 2.67 & $1.79-4.00$ & $<0.0001^{*}$ \\
0.4 mg/dL & & & \\
CPB time $>115$ min & 3.09 & $2.04-4.68$ & $<0.0001^{*}$ \\
\hline OR=odd
\end{tabular}

OR=odds ratio $; C I=$ confidence interval $;=$ number of individuals; $M=$ male; $F=$ female $; A B=$ intra-aortic balloon; $A F=$ atrial fibrillation; $B M I=$ body mass index; UCor=Coronary Unit; $C P B=$ cardiopulmonary bypass; *statistically significant 


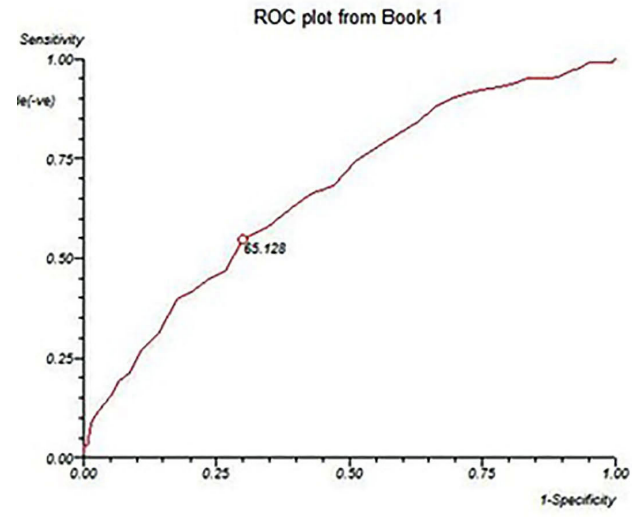

ROC plot from Book 1

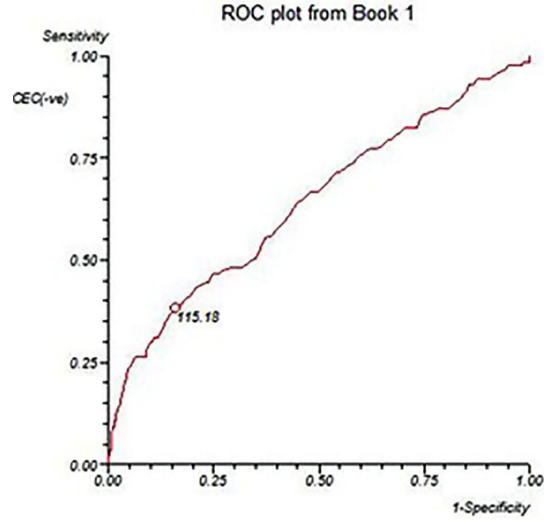

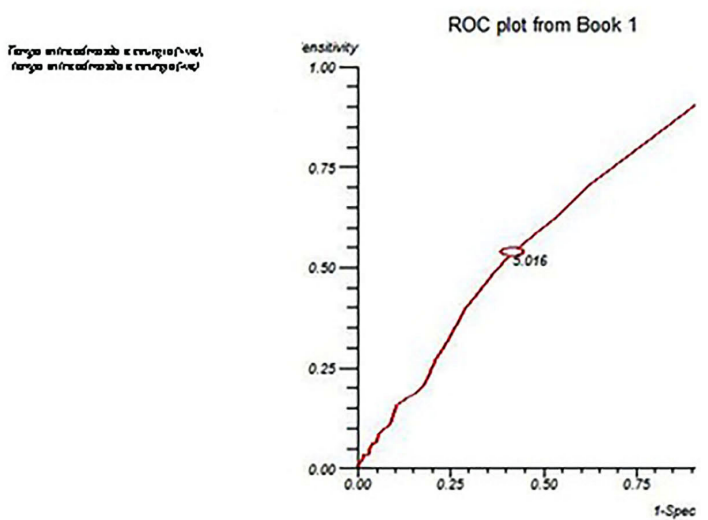

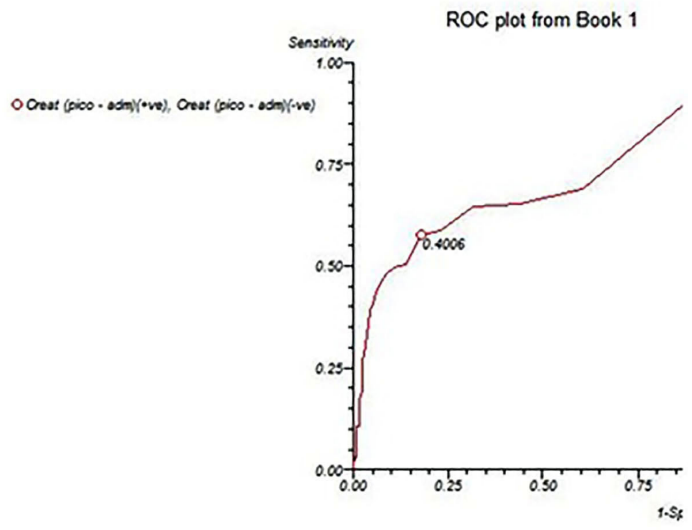

Fig. 1 - ROC curves (receiver operating characteristics) of age, time between hospital admission and surgery, cardiopulmonary bypass time and creatinine peak-admission for death up to 30 days.

Regarding change in serum creatinine (peak-admission), the relative risk of death is $167 \%$ higher when this variation is $\geq 0.4 \mathrm{mg} / \mathrm{dL}(\mathrm{OR}=2.67,95 \%$ CI 1.79 to $4.00 ; P<0.001)$.

As for the CPB time, the relative risk of death is $209 \%$ higher when it is above 115 minutes $(\mathrm{OR}=3.09,95 \% \mathrm{CI} 2.04$ to $4.68 ; P<0.001)$.

\section{DISCUSSION}

This study identified seven risk factors for mortality in patients undergoing coronary artery bypass grafting with cardiopulmonary bypass. In patients who died, the most common variables included male, pulmonary complications, use of intra-aortic balloon and type I neurological lesion. After logistic regression, risk factors for mortality were as follows: dialysis $(\mathrm{OR}=7.61)$, neurological damage type $\mathrm{I}(\mathrm{OR}=4.42)$, use of intra-aortic balloon $(\mathrm{OR}=3.38)$, cardiopulmonary bypass time $(\mathrm{OR}=3.09)$, creatinine peak - Intake $>0.4 \mathrm{mg} / \mathrm{dL}$
$(\mathrm{OR}=2.67)$, age $>65$ years $(\mathrm{OR}=2.31)$ and time between hospital admission and surgery $(\mathrm{OR}=1.53)$.

In this research, the mortality rate was $8.7 \%$, close to that recorded by DATASUS for CABG, or that is, $7 \%{ }^{[18]}$. In the period 2005-2007, Piegas et al. ${ }^{[10]}$ analyzed 63,272 CABG surgeries performed in 191 hospitals and found that the mortality rate was $6.2 \%$. Cadore et al. ${ }^{[14]}$, investigating 2,809 patients undergoing $\mathrm{CABG}$ alone or combined with valve replacement reported that the mortality rate was $10 \%$. It is noteworthy that the performance of combined surgery increases the risk of mortality.

These mortality rates are higher than in countries like the United States $(2.9 \%)^{[11]}$ and Canada $(1.7 \%)^{[12]}$, possibly due to the high prevalence of cardiovascular risk factors among Brazilian who underwent $\mathrm{CABG}^{[13]}$. On the other hand, the comparison of surgical results in national centers for European and North American centers is inadequate, because both the registration of the Society of Thoracic Surgeons (STS) 
as the UK Cardiac Surgical Register are volunteers, while DATASUS is administrative.

In this study, the peak-admission creatinine $\geq 0.4 \mathrm{mg} /$ $\mathrm{dL}$ was considered a risk factor for death. This finding was similar to that found by Machado et al. ${ }^{[15]}$ who studied 817 patients with acute kidney injury (AKI), and found that the creatinine peak-admission $\geq 0.3 \mathrm{mg} / \mathrm{dl}$ was an independent predictor of death in 30 days after on-pump CABG. However, these authors used the criterion proposed by Acute Kidney Injury Network (AKIN) classification, or that is, percentage increase $(\geq 50 \%)$ or absolute $(\geq 0.3 \mathrm{mg} / \mathrm{dL})$ of serum creatinine characterizes AKI. In this research, the value of creatinine peak-admission $\geq 0.4 \mathrm{mg} / \mathrm{dL}$ was considered as the cutoff point for death by the ROC curve.

The assessment of renal function by serum creatinine in patients undergoing $\mathrm{CABG}$ with $\mathrm{CPB}$ is essential because even a subclinical increase is considered independent predictor of death within 30 days after CABG in patients with normal renal function or preoperative renal injury ${ }^{[19]}$. In addition, $\mathrm{AKI}$ after $\mathrm{CABG}$ is common complication that increases the length of hospital stay and ICU and is associated with high morbidity and mortality rates ${ }^{[16,20]}$ with prognostic importance.

Of the 1,628 patients undergoing CABG with $\mathrm{CPB}, 40$ $(2.5 \%)$ required dialysis postoperatively. The need for dialysis is observed in up to $30.6 \%$ of $\operatorname{cases}^{[16,20,21]}$. Yehia et al. ${ }^{[21]}$, assessing 104 patients undergoing $\mathrm{CABG}$, found that $41.3 \%$ of them developed AKI after surgery, requiring dialysis in up to $9.6 \%$, mainly in those with preoperative renal injury. Santos et al. ${ }^{[16]}$ found that of 223 patients undergoing CABG with $\mathrm{CPB}$, dialysis was required in $4.9 \%$ of them.

In this series, of 40 patients requiring dialysis postoperatively, $23(57.5 \%)$ died, close to the mortality rate recorded by Santos et al. ${ }^{[16]}$ and Chertow et al. ${ }^{[20]} 636 \%(\mathrm{n}=223)$ and $63.7 \%(n=460)$, respectively. Despite this proximity, the comparison between the studies is complex because it is related to the number and characteristics of hospitals involved in each study, patient profiles and sample size.

The relative risk of death in patients requiring dialysis postoperatively was significantly higher $(\mathrm{OR}=7.61,95 \% \mathrm{CI}$ 3.58 to $16.20 ; P<0.0001)$. This finding is consistent with the literature. According Chertow et al. ${ }^{[20]}$ the need for dialysis increases by 7.9 times the odds ratio of death among these patients. When there is severe renal injury enough to require dialysis, a sharp increase in mortality occurs ${ }^{[20]}$. Therefore, the identification of preoperative risk factors for AKI may contribute to the use of preventive strategies to minimize risk and improve treatment of this injury.

In this series, age $>65$ years was considered a risk factor for mortality. This finding was similar to that found by Rocha et al. ${ }^{[22]}$ in patients aged $\geq 70$ years. Naughton et al. ${ }^{[23]}$ studied 3,683 patients undergoing $\mathrm{CABG}$ and found that age $\geq 75$ years was an independent risk factor for mortality within 30 days. However, Aikawa et al. ${ }^{[4]}$ investigating the impact of CABG on 253 elderly patients, found that age $\geq 65$ years was not associated with death variable.

Considering the increased prevalence of CAD with age ${ }^{[24]}$, it is possible that an increasing number of elderly patients are candidates to CABG in the coming years. Therefore, a careful assessment of cardiac and non-cardiac variables during pre-, intra- and post-operative patients over 65 years is necessary because age can be associated with other severe comorbidities such as renal and neurological injuries in the postoperative period.

In this study, the CPB time was identified as a risk factor for mortality. The average time in patients undergoing $\mathrm{CABG}$ was $94.4 \mathrm{~min}$. In the literature, this time varies from 65.8 to $120 \min ^{[13,16,24]}$. In patients who died, the mean CPB time was higher (118.58 $\mathrm{min})$, confirming the findings of Oliveira et al. ${ }^{[13]}$.

The relative risk of death is $209 \%$ higher when the CPB time is higher than 115 minutes $(\mathrm{OR}=3.09,95 \%$ CI 2.04 to 4.68; $P<0.001)$. A major concern related to cardiopulmonary bypass is systemic inflammatory response syndrome (SIRS), characterized by clinical changes in ventricular function, lung and kidney, coagulation disorders, susceptibility to infections, abnormal vascular permeability and fluid accumulation in the interstitium, leukocytosis, vasoconstriction and hemolysis ${ }^{[25]}$. It is noteworthy that despite these changes, the body's ability to reverse this situation, and the use of corticosteroids, an effective alternative in reducing the systemic effects caused by the release of cytokines during and after $\mathrm{CPB}^{[26]}$, can reduce morbidity and mortality rate.

On the other hand, the CPB substitutes the cardiopulmonary functions, seeks to maintain cell integrity, structure, function and metabolism of organs and individual systems, enabling more complex and longer surgeries ${ }^{[27]}$ such as coronary artery bypass grafting.

In this study, the patients studied $(n=1,628) 4.4 \%$ had neurological damage type I. This finding was consistent with the two largest series in the literature that assessed more than 16,000 patients undergoing CABG with incidences of 2 to $4.6 \%{ }^{[28,29]}$. In our country, Guaragna et al. ${ }^{[17]}$ assessing 1,760 patients undergoing $\mathrm{CABG}$ with $\mathrm{CPB}$ found this lesion in $3 \%$ of them.

Among the patients who died ( $\mathrm{n}=141), 19 \%$ had neurological injury type I. This result is consistent with previous studies that showed high mortality (13-41\%) in patients who have had this injury after $\mathrm{CABG}^{[30]}$.

The relative risk of death in patients with type I neurological injury postoperatively was significantly higher $(\mathrm{OR}=4.42,95 \% \mathrm{CI} 2.48$ to $7.81 ; P<0.0001)$. This finding was similar to that observed by Guaragna et al. ${ }^{[17]}$, and the relative risk of death was 4.6 times higher in patients with this injury. Considering the severity of this type of injury in postoperative patients undergoing $\mathrm{CABG}$ with $\mathrm{CPB}$, some preventive 
measures can be adopted as an individualized management strategy for patients with previous cerebrovascular disease, including minimal manipulation of the aorta and maintenance of the highest pressure gradient during CPB.

Among the 141 patients undergoing $\mathrm{CABG}$ with $\mathrm{CPB}$ who died, $21 \%$ of them used intra-aortic balloon. This rate was consistent with the literature. In a review of 27 years of IAB use by the Massachusetts General Hospital, mortality among patients who received IAB ranged from 13.6 to $35 \%{ }^{[31]}$.

According to Christenson et al. ${ }^{[32]}$, the preoperative prophylactic use of IAB has great value to prevent trans- and postoperative complications. In this sample, the relative likelihood of patients who used this type of device for ventricular assistance to die was significantly high. The use of IAB is related to the existence of low left ventricular ejection fraction and or severe coronary lesions, indicating poor heart condition, which can increase morbidity and mortality rate in patients undergoing $\mathrm{CABG}$ with $\mathrm{CPB}$.

In patients who died, the median time between hospital admission and surgery was 6 days. Oliveira et al. ${ }^{[13]}$ found that mortality was higher among patients with time of preoperative stay less than 3 days.

Importantly, the hospital stay before surgery may be related to the clinical severity, suggesting an advanced degree of coronary involvement that may result in increased morbidity and mortality rate in the postoperative period.

As limitations of the study we should mention that it is not randomized. In addition, the influence of preoperative, intraoperative and postoperative mortality of patients undergoing $\mathrm{CABG}$ with $\mathrm{CPB}$ needs more long-term scientific research. The clinical importance of the results obtained herein reinforces the multidisciplinary approach in patients undergoing coronary artery bypass grafting, especially in the postoperative period.

The identification of risk factors for mortality is critical, since this knowledge can support interventions aimed at the planning and execution of new preventive strategies, and minimizing the complications associated with this surgery. This information may also be used as an important care quality indicator in the postoperative period, in this case provided by SUS.

\section{CONCLUSION}

In patients undergoing coronary artery bypass grafting with cardiopulmonary bypass who died, the more frequent preoperative, intraoperative and postoperative variable were male, pulmonary complications, use of intra-aortic balloon and neurological damage type I.

Dialysis, neurological damage type I, use of intra-aortic balloon, CPB time ( $>115$ minutes), creatinine peak-admission $>0.4 \mathrm{mg} / \mathrm{dL}$, age $>65$ years and time between hospital admission and surgery were identified as risk factors for mortality in the postoperative period.

\begin{tabular}{|ll|}
\hline Authors' roles \& responsibilities \\
\hline CAS & $\begin{array}{l}\text { Analysis and / or interpretation of data, final approval of the } \\
\text { manuscript, study design, conduct of operations and/or ex- } \\
\text { periments, manuscript writing or critical review of its con- } \\
\text { tent } \\
\text { Analysis and/or interpretation of data, statistical analysis, } \\
\text { manuscript writing or critical review of its content }\end{array}$ \\
MABO & $\begin{array}{l}\text { Conduct of operations and/or experiments, manuscript writ- } \\
\text { ing or critical review of its content }\end{array}$ \\
ACB & $\begin{array}{l}\text { Conception and design of the study, implementation of oper- } \\
\text { ations and/or experiments }\end{array}$ \\
JCMB & $\begin{array}{l}\text { Analysis and/or interpretation of data, final approval of the } \\
\text { manuscript }\end{array}$ \\
MAS & $\begin{array}{l}\text { Final approval of the manuscript, design and study design, } \\
\text { manuscript writing or critical review of its content } \\
\text { Analysis and/or interpretation of data, statistical analysis, } \\
\text { study design } \\
\text { Analysis and/or interpretation of data, final approval of the } \\
\text { manuscript, manuscript writing or critical review of its con- } \\
\text { tent }\end{array}$ \\
DMB &
\end{tabular}

\section{REFERENCES}

1. World Health Organization. Global status report on noncommunicable diseases 2010. Geneva: World Health Organization; 2011.

2. World Health Organization. Global atlas on cardiovascular disease prevention and control. Geneva: World Health Organization; 2011.

3. Brasil. Ministério da Saúde. Datasus. Banco de dados do Sistema Único de Saúde. Brasília: Ministério da Saúde; 2010. Disponível em: http://www.datasus.org.br

4. Aikawa P, Cintra AR, Leite CA, Marques RH, Silva CT, Afonso MS, et al. Impact of coronary artery bypass grafting in elderly patients. Rev Bras Cir Cardiovasc. 2013;28(1):22-8.

5. Dallan LAO, Jatene FB. Revascularização miocárdica no século XXI. Rev Bras Cir Cardiovasc 2013;28:137-44.

6. Stevens LM, Carrier M, Perrault LP, Hébert Y, Cartier R, Bouchard $\mathrm{D}$, et al. Influence of diabetes and bilateral internal thoracic artery grafts on long-term outcome for multivessel coronary artery bypass grafting. Eur J Cardiothorac Surg. 2005;27(2):281-8.

7. Kieser TM, Lewin AM, Graham MM, Martin BJ, Galbraith PD, Rabi $\mathrm{DM}$, et al. Outcomes associated with bilateral internal thoracic artery grafting: the importance of age. Ann Thorac Surg. 2011;92(4):1269-75.

8. Galbut DL, Kurlansky PA, Traad EA, Dorman MJ, Zucker M, Ebra G. Bilateral internal thoracic artery grafting improves long-term survival in patients with reduced ejection fraction: a propensity-matched study with 30-year follow-up. J Thorac Cardiovasc Surg. 2012;143(4):844-853.

9. Sussenbach CP, Guaragna JC, Castagnino RS, Piccoli J, Albuquerque LC, Goldani MA, et al. Unstable angina does not increase 
mortality in coronary artery bypass graft surgery. Rev Bras Cir Cardiovasc. 2013;28(3):391-400.

10. Piegas LP, Bittar OJNV, Haddad N. Cirurgia de revascularização miocárdica: resultados do Sistema Único de Saúde. Arq Bras Cardiol. 2009;93(5):555-60.

11. Hannan EL, Wu C, Ryan TJ, Bennett E, Culliford AT, Gold JP, et al. Do hospital and surgeons with higher coronary artery bypass graft surgery volumes still have lower risk-adjusted mortality rates? Circulation. 2003;108(7):795-801.

12. Cartier R, Bouchout O, El-Hamamsy I. Influence of sex and age on long-term survival in systematic off-pump coronary artery bypass surgery. Eur J Cardiothorac Surg. 2008;34(4):826-32.

13. Oliveira EL, Westphal GA, Mastroeni MF. Características clínicodemográficas de pacientes submetidos a cirurgia de revascularização do miocárdio e sua relação com a mortalidade. Rev Bras Cir Cardiovasc. 2012;27(1):52-60.

14. Cadore MP, Guaragna JCVC, Anacker JFA, Albuquerque LC, Bodanese LC, Piccoli JCE, et al. Proposição de um escore de risco cirúrgico em pacientes submetidos à cirurgia de revascularização miocárdica. Rev Bras Cir Cardiovasc. 2010;25(4):447-56.

15. Machado MN, Miranda RC, Takakura IT, Palmegiani E, Santos CA, Oliveira MA, et al. Acute kidney injury after on-pump coronary artery bypass graft surgery. Arq Bras Cardiol. 2009;93(3):247-52.

16. Santos FO, Silveira MA, Maia RB, Monteiro MD, Martinelli $\mathrm{R}$. Acute renal failure after coronary artery bypass surgery with extracorporeal circulation: incidence, risk factors, and mortality. Arq Bras Cardiol. 2004;83(2):150-4.

17. Guaragna JCVC, Bolsi DC, Jaeger CP, Melchior R, Petracco JB, Facchi LM, et al. Preditores de disfunção neurológica maior após cirurgia de revascularização miocárdica isolada. Rev Bras Cir Cardiovasc. 2006;21(2):173-9.

18. Ribeiro AL, Gagliardi SP, Nogueira JL, Silveira LM, Colosimo EA, Lopes do Nascimento CA. Mortality related to cardiac surgery in Brazil, 2000-2003. J Thorac Cardiovasc Surg. 2006;131(4):907-9.

19. Tolpin DA, Collard CD, Lee VV, Virani SS, Allison PM, Elayda MA, et al. Subclinical changes in serum creatinine and mortality after coronary artery bypass grafting. J Thorac Cardiovasc Surg. 2012;143(3):682-8.

20. Chertow GM, Levy EM, Hammermeister KE, Grover F, Daley J. Independent association between acute renal failure and mortality following cardiac surgery. Am J Med. 1998;104(4):343-8.
21. Yehia M, Collins JF, Beca J. Acute renal failure in patients with pre-existing renal dysfunction following coronary artery bypass grafting. Nephrology (Carlton). 2005;10(6):541-3.

22. Rocha AS, Pittella FJ, Lorenzo AR, Barzan V, Colafranceschi AS, Brito JO, et al. Age influences outcomes in 70-year or older patients undergoing isolated coronary artery bypass graft surgery. Rev Bras Cir Cardiovasc. 2012;27(1):45-51.

23. Naughton C, Feneck RO, Roxburgh J. Early and late predictors of mortality following on-pump coronary artery bypass graft surgery in the elderly as compared to a younger population. Eur J Cardiothorac Surg. 2009;36(4):621-7.

24. Rodrigues AJ, Evora PRB, Bassetto S, Alves Júnior L, Scorzoni Filho A, Araújo WF, et al. Fatores de risco para lesão renal aguda após cirurgia cardíaca. Rev Bras Cir Cardiovasc. 2009;24(4):441-6.

25. Hall RI, Smith MS, Rocker G. The systemic inflammatory response to cardiopulmonary bypass: pathophysiological, therapeutic, and pharmacological considerations. Anesth Analg. 1997;85(4):766-82.

26. Inaba H, Kochi A, Yorozu S. Suppression by methylprednisolone of augmented plasma endotoxin-like activity and interleukin-6 during cardiopulmonary bypass. Br J Anaesth. 1994;72(3):348-50.

27. Souza MHL, Elias DO. Fundamentos de extracorpórea. Rio de Janeiro: Centro Editorial Alfa Rio; 1995.

28. Stamou SC, Hill PC, Dangas G, Pfister AJ, Boyce SW, Dullum $\mathrm{MK}$, et al. Stroke after coronary artery bypass: incidence, predictors, and clinical outcome. Stroke. 2001;32(7):1508-13.

29. Bucerius J, Gummert JF, Borger MA, Walther T, Doll N, Onnasch $\mathrm{JF}$, et al. Stroke after cardiac surgery: a risk factor analysis of 16,184 consecutive adult patients. Ann Thorac Surg. 2003;75(2):472-8.

30. Roach GW, Kanchuger M, Mangano CM, Newman M, Nussmeier $\mathrm{N}$, Wolman R, et al. Adverse cerebral outcomes after coronary bypass surgery. Multicenter Study of Perioperative Ischemia Research Group and the Ischemia Research and Education Foundation Investigators. N Eng J Med. 1996;335(25):1857-63.

31. Torchiana DF, Hirsch G, Buckley MJ, Hahn C, Allyn JW, Akins $\mathrm{CW}$, et al. Intraaortic balloon pumping for cardiac support: trends in practice and outcome, 1968-1995. J Thorac Cardiovasc Surg. 1997;113(4):758-64.

32. Christenson JT, Simonet F, Schmuziger M. The effect of preoperative intra-aortic balloon pump support in high risk patients requiring myocardial revascularization. J Cardiovasc Surg (Torino). 1997;38(4):397-402. 